\title{
Strength Properties of Geopolymer Concrete with Ground Granulated Blast Furnace Slag and Metakaolin
}

\author{
Ganesan Nagalingam, Ramesh Babu Chokkalingam, Meyyappan PL
}

\begin{abstract}
In this study, geopolymer concrete is prepared by using 100\% Ground Granulated Blast furnace Slag (GGBS). Then the GGBS is replaced by Metakaolin from 0 to $25 \%$ with the variation of $5 \%$ for preparing the specimens. The activator solution consists of Sodium hydroxide of 12 Molarity and sodium silicate in the ratio of 1: $2.5 .550 \mathrm{~kg} / \mathrm{m}^{3}$ of $G G B S$ is used in this study. A carboxylic based admixture called La Hypercrete S25 is added in the mix by $1 \%$ of the weight of GGBS to increase the workability. The studies conducted on the specimens are compression test, split tensile test and flexure test. For conducting the compression test, 54 concrete cubes of size 100mm x 100mm x 100mm are cast for testing at 7, 14 and 28 days. For splitting tensile strength, 54 concrete cylinders with $100 \mathrm{~mm}$ dia and $200 \mathrm{~mm}$ height are cast for testing at 7, 14 and 28 days. The flexure test specimens are beams of $500 \mathrm{~mm}$ length and 100mm $\times 100 \mathrm{~mm}$ in cross section are cast. These are 54 in numbers . Specimens are cast by replacing the GGBS by Metakaolin in 5, 10, 15, 20 and 25\%. All the specimens are cured for 7,14 and 28 days and tested for compression, split tensile and flexure. The test results reveal that the strengths are gradually increasing for 5, 10 and $15 \%$ replacement of GGBS by Metakaolin and give the highest value for $20 \%$ in all the tests. It also shows further increased replacements reduces the test values. It proves that geopolymer concrete performs well in strength properties with GGBS and Metakaolin.
\end{abstract}

Keywords : activator, admixture, Geopolymer concrete, GGBS, Metakaolin

\section{INTRODUCTION}

Usage of geopolymer concrete in construction industry minimizes the production of cement which pollutes the atmosphere through the emission of green house gases. Many studies reveal that any industrial waste can be converted as a concrete making material. Already many attempts have been made and succeeded in using the geopolymer concrete because of its excellent mechanical properties, acid resistance

and fire resistance [1, 2]. Many works have been already completed with fly ash and GGBS in the place of cement. The

Revised Manuscript Received on December 05, 2019.

* Correspondence Author

*Ganesan Nagalingam, Department of Civil Engineering, Kalasalingam Academy of Research and Education, Krishnankoil, Virudhunagar District, Tamilnadu .Email: civilganesan139@gmail.com

Ramesh Babu Chockkalingam, Department of Civil Engineering, Kalasalingam Academy of Research and Education Krishnankoil, Virudhunagar District, Tamilnadu . Email: babussr@gmail.com

Meyyappan PL, Department of Civil Engineering, Kalasalingam Academy of Research and Education ,Krishnankoil, Virudhunagar District, Tamilnadu . Email: meyyappan9881@gmail.com polycondensation of silica and alumina is responsible for the development of strength in geo polymer concrete [3] In most of the studies, the activator solution used consists of Sodium hydroxide and sodium silicate because of its thermal activation nature [4,5] Also many researchers have tried Metakaolin along with GGBS in geopolymer concrete for strength behaviour [6] Hence an attempt is made here to use GGBS and Metakaolin to study the strength properties of geopolymer concrete.

\section{MATERIALS}

\section{A. Ground granulated blast furnace slag (GGBS):}

The advantages of GGBS are high resistivity to sulphate attack and chemicals. It is the by-product of iron manufacture process in blast furnace. The specific gravity of GGBS used in this study is 2.9. The oxide compounds of GGBS are obtained from XRD analysis which is shown in Fig1.

\section{B. Metakaolin:}

Metakaolin is obtained by the calcination of kaolinite clay. It has high reactivity with alkali solutions. It is a very fine particle white in colour. The specific gravity of Metakaolin used in this study is 2.7 .

\section{Fine aggregate}

The river sand confirming to Zone 2 of IS 382- 2016 after sieving through $2.36 \mathrm{~mm}$ sieve is used as fine aggregate. The specific gravity of the fine aggregate used in this study is 2.80 and fineness modulus is 3.28[7]

\section{Coarse aggregate}

Crushed granite stones which confirms to IS: 383 - 1970 and retained in $4.75 \mathrm{~mm}$ sieve is used in this study. The specific gravity of the coarse aggregate is 2.808 and fineness modulus is 7.05 .

\section{E. Activator solution}

In this study, the activator solution used consists of Sodium hydroxide of 12 Molarity and sodium silicate in the ratio of 1: 2.5. This activator solution is prepared 24 hours before the casting of specimens.

\section{F. Admixture}

To increase the workability of geopolymer concrete, a modified carboxylic based ether known as La- Hypercrete S25 (HTS code 38244090) is added in the mix by $1 \%$ of the weight of GGBS.[8] 


\section{G. Mix proportion for the experimental work}

The proportions of materials used in this experimental work is tabulated in Table I below.[9]

Table- I: Materials for the experimental work

\begin{tabular}{|c|c|c|c|c|c|c|}
\hline Materials & BS & FA & CA & $\begin{array}{c}\text { Na } \\
\text { OH }\end{array}$ & $\begin{array}{c}\mathbf{N a}_{2} \\
\mathbf{S i O}_{3}\end{array}$ & $\begin{array}{c}\text { Ad-mixt } \\
\text { ure }\end{array}$ \\
\hline $\begin{array}{c}\text { Quantity } \\
\left(\mathrm{kg} / \mathrm{m}^{3}\right)\end{array}$ & 550 & $\begin{array}{c}689 \\
1\end{array}$ & 1113.2 & 55 & 137.5 & 5.5 \\
\hline
\end{tabular}
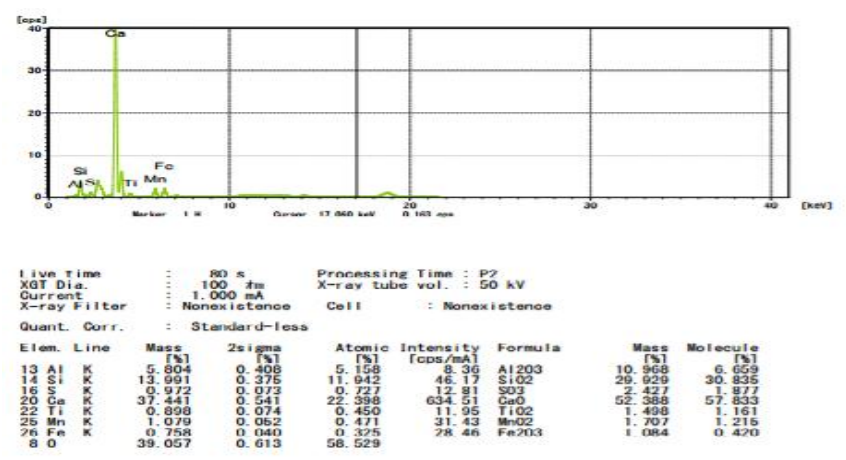

Fig.1. XRF Analysis of GGBS

\section{EXPERIMENTAL WORK}

A. Mix ID for various combinations of GGBS and Metakaolin

The Metakaolin and GGBS quantities used in various mix combinations are tabulated in Table II below.

Table- II: Metakaolin and GGBS quantities

\begin{tabular}{|c|c|c|c|c|c|c|}
\hline Mix ID & S1 & $\mathbf{2}$ & $\mathbf{3}$ & S4 & S5 & \begin{tabular}{c} 
6 \\
\hline $\begin{array}{c}\text { Metakaolin } \\
(\%)\end{array}$
\end{tabular} \\
\hline & 0 & 5 & 10 & 15 & 20 & 25 \\
\hline GGBS (\%) & 100 & 95 & 90 & 85 & 80 & 75 \\
\hline
\end{tabular}

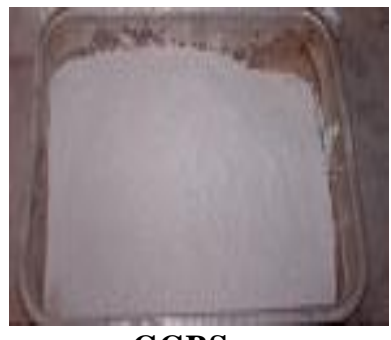

GGBS

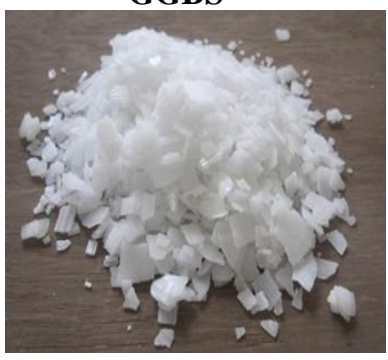

SODIUM HYDROXIDE

(FLAKES)

The various combinations of GGBS and Metakaolin used for preparing the specimens are listed in the Table II. GGBS and Metakaolin both are industrial waste materials. Many researchers have already proved that replacing cement by GGBS shows good result in strength properties. Similarly, the usage of Metakaolin in replacement of cement has proved excellent results. So, here an attempt is made to use both GGBS and Metakaolin together in concrete for complete replacement of cement.

\section{B. Compression Test:}

For determining the compressive strength of geopolymer concrete, cubes of $100 \mathrm{~mm}$ size is cast with $100 \%$ GGBS. The materials are weighed accurately and cubes are cast for testing at 7, 14 and 28 days. Three cubes are cast for each testing day in compression. After 24 hours of curing of specimens at room temperature, the cubes are removed from the moulds and subjected to water curing for the required days. Cube specimens are also cast for 5, 10,15,20 and 25\% replacement of GGBS by Metakaolin for testing at 7,14 and 28 days. After the required days of curing, the cubes are tested for compression in compression testing machine as shown in Fig 2. The average compressive strength results are tabulated in the Table III shown below and the comparison of compressive strength results are explained through Fig 3.

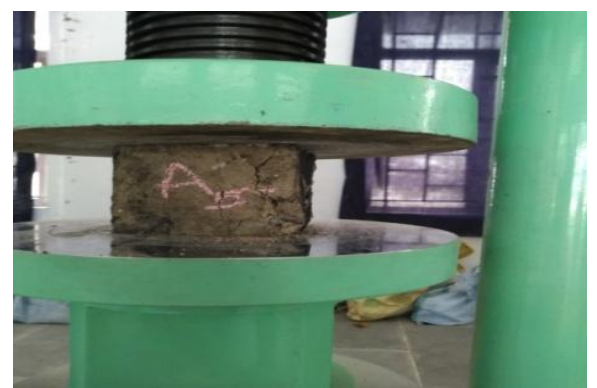

Fig. 2 .Cubes tested for compression

Table- III: Average Compressive strength test results

\begin{tabular}{|c|c|c|c|c|c|c|}
\hline $\begin{array}{c}\text { Age of } \\
\text { curing }\end{array}$ & S1 & S2 & S3 & S4 & S5 & S6 \\
\hline 7 & 32.74 & $\begin{array}{c}33.7 \\
9\end{array}$ & $\begin{array}{c}35.7 \\
5\end{array}$ & $\begin{array}{c}38.1 \\
1\end{array}$ & 38.97 & 36.42 \\
\hline & & 35.4 & $\begin{array}{c}37.2 \\
2\end{array}$ & $\begin{array}{c}38.2 \\
1\end{array}$ & 39.59 & 37.39 \\
\hline 14 & 33.51 & 8 & 2 & & \\
& & 40.7 & 42.6 & 44.5 & & \\
28 & 38.22 & 3 & 8 & 1 & 46.24 & 41.15 \\
\hline
\end{tabular}

\section{COMPRESSIVE STRENGTH TEST RESULT}

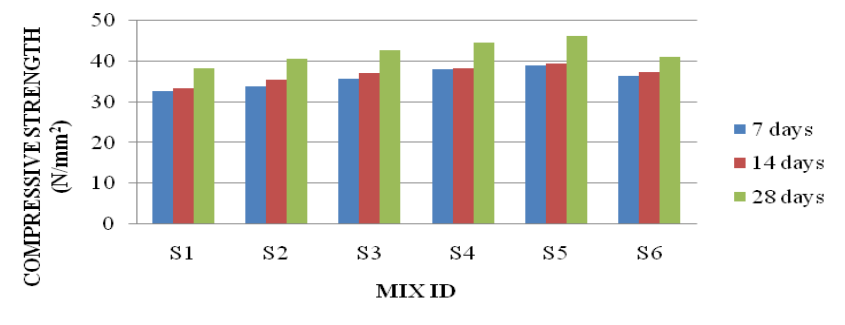

Fig.3. Comparison of Compressive test results

\section{Split tensile Test:}

For determining the splitting tensile strength of geopolymer concrete, cylinders of $100 \mathrm{~mm}$ dia and $200 \mathrm{~mm}$ height are cast. The specimens are cast for $100 \%$ GGBS and for other replacements of GGBS by Metakaolin. The specimens

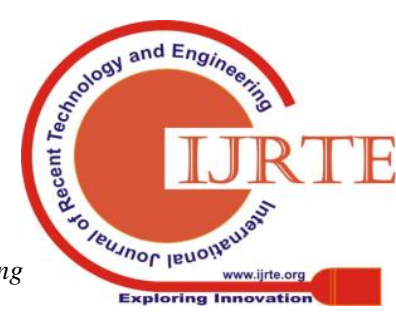


are cast as per the codal provisions. The cylinder specimens are tested at 7, 14 and 28 days. The testing of specimen is shown in Fig 4 and the average splitting tensile strength results are tabulated in the Table IV shown below. The comparison of splitting tensile strength results are shown in Fig 5.

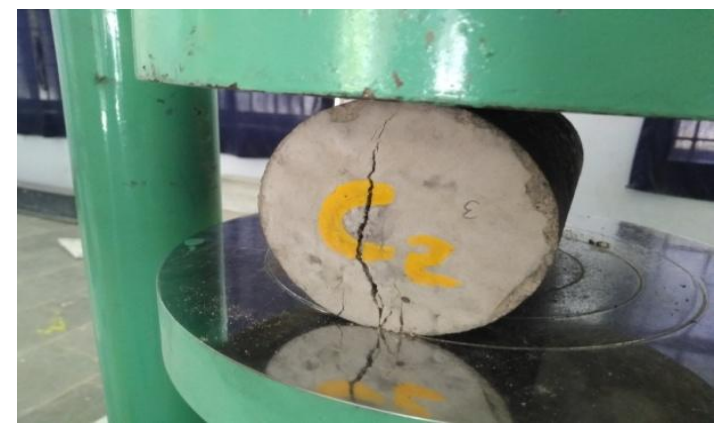

Fig.4. Split tensile test set up

Table- IV: Average split tensile strength results

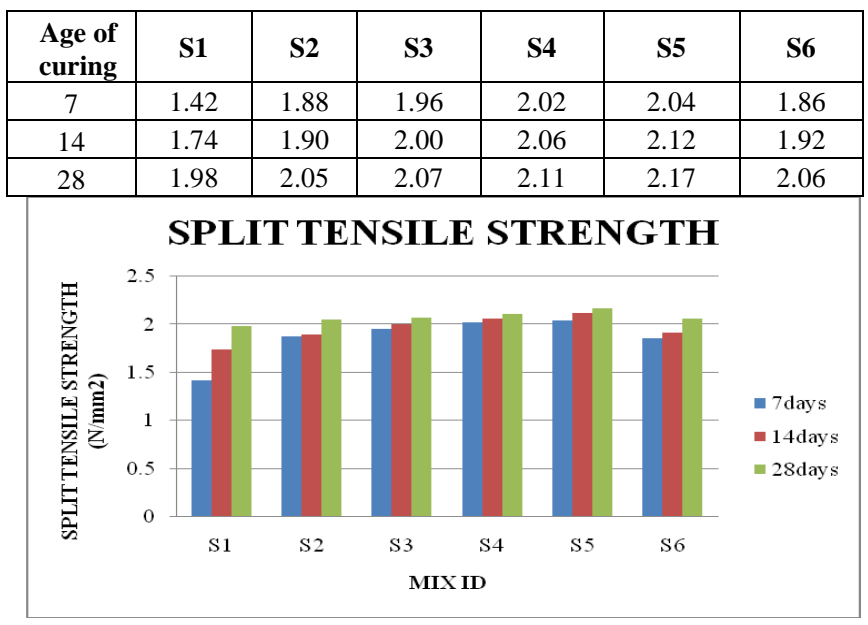

Fig.5. Comparison of split tensile test results

\section{Flexure Test:}

The flexure is performed by casting beam specimens of $500 \mathrm{~mm}$ length and $100 \mathrm{~mm} \times 100 \mathrm{~mm}$ cross sections. The beams are cured for 7, 14 and 28 days and tested for flexural strength. The testing of specimen is shown in Fig 6.The average flexural strength values are tabulated in Table $\mathrm{V}$ shown below. The comparison of flexure strength results are shown in Fig 7.

Fig.6. Flexure test set up

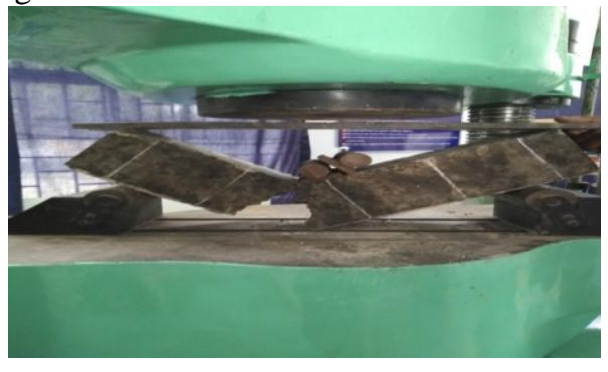

Table- V: Average flexural strength results

\begin{tabular}{|c|c|c|c|c|c|c|}
\hline $\begin{array}{c}\text { Age of } \\
\text { curing }\end{array}$ & S1 & S2 & S3 & S4 & S5 & S6 \\
\hline 7 & 12.13 & 12.60 & 13.13 & 13.51 & 14.06 & 12.60 \\
\hline 14 & 12.40 & 12.76 & 13.23 & 13.80 & 14.30 & 12.83 \\
\hline 28 & 12.60 & 13.00 & 13.30 & 13.85 & 14.65 & 12.90 \\
\hline
\end{tabular}

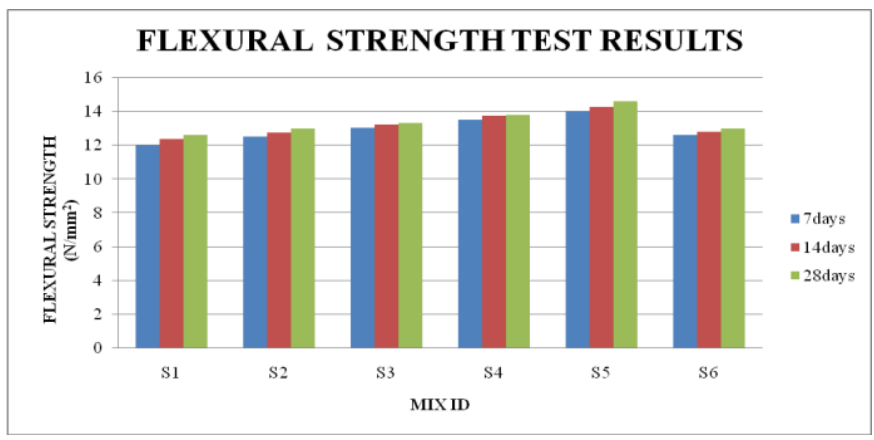

Fig.7. Comparison of flexural strength test results

\section{RESULTS WITH DISCUSSION}

\section{A. Discussion on compressive strength test results}

From the compressive strength test results of Table 3, it is found that at the age of 7 days, the average compressive strength of S1 specimens (100\% GGBS and 0\% Metakaolin) is $32.74 \mathrm{~N} / \mathrm{mm}^{2}$. This value increased further for $5 \%, 10 \%$, $15 \%$, and $20 \%$ of GGBS replacement and reached the maximum value of $38.97 \mathrm{~N} / \mathrm{mm}^{2}$. Further, for $25 \%$ of Metakaolin in GGBS replacement this value was reduced to $36.42 \mathrm{~N} / \mathrm{mm}^{2}$. At the age of 14days, the average compressive strength for $\mathrm{S} 1$ specimen is $33.51 \mathrm{~N} / \mathrm{mm}^{2}$. This value increased further and reached the maximum value of 39.59 $\mathrm{N} / \mathrm{mm}^{2}$ for $20 \%$ of Metakaolin in GGBS replacement. Similarly for 28days, the maximum value of $46.24 \mathrm{~N} / \mathrm{mm}^{2}$ was obtained for S5 mix specimens and their compressive strength was $38.22 \mathrm{~N} / \mathrm{mm}^{2}$ for $0 \%$ replacement. From all the compressive strength test results, the mix with $80 \%$ GGBS, $20 \%$ Metakaolin gives better results than other replacement. It shows that the compressive strength value increases with time.

\section{B. Discussion on splitting tensile strength test results}

From the splitting strength results of Table 4, it is observed that at the age of 7days, the average split tensile strength of S1 specimens (100\% GGBS and 0\% Metakaolin) is $1.42 \mathrm{~N} / \mathrm{mm}^{2}$. This value increased further for $5 \%, 10 \%, 15 \%, 20 \%$ of GGBS replacement and reached the maximum value of 2.04 $\mathrm{N} / \mathrm{mm}^{2}$. Further, for $25 \%$ of Metakaolin in GGBS replacement this value was reduced to $1.86 \mathrm{~N} / \mathrm{mm}^{2}$.At the age of 14days, the average split tensile for $\mathrm{S} 1$ specimen is 1.74 $\mathrm{N} / \mathrm{mm}^{2}$. This value increased further and reached the maximum value of $2.12 \mathrm{~N} / \mathrm{mm}^{2}$ for $20 \%$ of Metakaolin in GGBS replacement and this value is reduced to $1.92 \mathrm{~N} / \mathrm{mm}^{2}$ for $25 \%$ replacement. Similarly for 28days, the maximum value of $2.17 \mathrm{~N} / \mathrm{mm}^{2}$ was obtained for S5 mix specimens and the split tensile strength was $1.98 \mathrm{~N} / \mathrm{mm}^{2}$ for $0 \%$ replacement From all the split tensile strength test results, the mix with $80 \%$ GGBS, $20 \%$ 
Metakaolin gives better results than other replacement. It also shows that there is an increment with increase in age of concrete.

\section{Discussion on flexural strength test results}

From the flexural strength results of Table 5, it is evident that at the age of 7days, the average flexural strength of $\mathrm{S} 1$ specimens (100\% GGBS and 0\% Metakaolin) is 12.13 $\mathrm{N} / \mathrm{mm}^{2}$. This value increased further for $5 \%, 10 \%, 15 \%$, and $20 \%$ of GGBS replacement and reached the maximum value of $14.06 \mathrm{~N} / \mathrm{mm}^{2}$. Further, for $25 \%$ of Metakaolin in GGBS replacement this value was reduced to $12.60 \mathrm{~N} / \mathrm{mm}^{2}$. At the age of 14days, the average flexural strength for $\mathrm{S} 1$ specimen is $12.40 \mathrm{~N} / \mathrm{mm}^{2}$. This value increased further and reached the maximum value of $14.30 \mathrm{~N} / \mathrm{mm}^{2}$ for $20 \%$ of Metakaolin in GGBS replacement. Similarly for 28days, the maximum value of $14.65 \mathrm{~N} / \mathrm{mm}^{2}$ was obtained for S5 mix specimens and their flexural strength was $12.60 \mathrm{~N} / \mathrm{mm}^{2}$ for $0 \%$ replacement .From all the flexural strength test results, the mix with $80 \%$ GGBS, 20\% Metakaolin gives better results than other replacement. Also this test proves that geopolymer concrete performs well for flexure also with age. It is observed that, the activator ratio 1:1.25 polymerizes the materials (GGBS and Metakaolin and aggregates) in to the molecular chains and its networks is enhanced the binding property. This ensures the good Geopolymerization process for that concerned the activator ratio due to the formation of effective alumina-silicate gel which assures the binding property of the concrete and attainment of strength.

\section{CONCLUSION}

The conclusions based on the limited observations from the present investigation on properties of Metakaolin and GGBS based Geopolymer concrete is as follows.

(i) The compression, flexural and split tensile strength initially increases and then start decreases with increased Metakaolin.

(ii) Geopolymer concrete with $80 \%$ GGBS and $20 \%$ Metakaolin gives good values in all the three strength studies.

\section{REFERENCES}

1. B.Singh, G.Ishwarya, Gupta M. Bhattacharyya "Geopolymer concrete: A review of some recent developments" Construction and Building Materials 2015, pp. 78-90

2. Daniel L.Y. Kong, Jay G. Sanjayan "Effect of elevated temperatures on geopolymer paste, mortar and concrete" Cement and Concrete Research 40 pp. 334-339

3. J.Davidovits, "Geopolymer chemistry and application," 2nd edition, Saint-Quentin (France); Institute Geopolymer; 2008.

4. Ramesh Babu Chockalingam, N Ganesan , "A Study on the Strength Development of Geopolymer concrete using Fly ash" International Journal of Engineering and Technology 2019, pp. 163-167

5. P.Chindaprasirt, W.Chalee," Effect of sodium hydroxide concentration on chloride penetration and steel corrosion of fly ash based geopolymer concrete under marine site "Construction and Building Materials , 2014, pp. 303- 310

6. B Sarath Chandra Kumar, K Ramesh , P Poluraju "An Experimental investigation on flexural behaviour of GGBS and Metakaolin based Geopolymer concrete" ARPN Journal of Engineering and Applied Sciences . 2014, pp. 2052 - 2062

7. Indian Standard Code of practice for specification for coarse and fine aggregates from natural sources for concrete, IS: 383 - 1970, Bureau of Indian Standards, New Delhi, India
8. Indian Standard code of practice for specifications for admixtures for concrete IS: 9103-1999, Bureau of Indian Standards, New Delhi, India

9. Indian Standard Code for recommended guidelines for concrete mix design IS: 10262-2009,Bureau of Indian Standards, New Delhi.

\section{AUTHORS PROFILE}

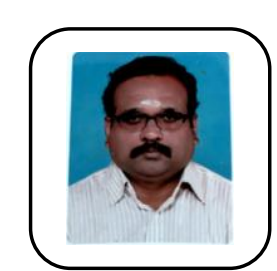

Ganesan Nagalingam completed his UG in Civil Engg. from A.C.Tech, Karaikudi and PG in Structural Engineering from Annamalai University, and pursuing his $\mathrm{PhD}$ from Kalasalingam Academy of Research and Education. He has more than twenty five years of experience in teaching and industry. His concrete,high performance concrete etc. areas of research include geopolymer

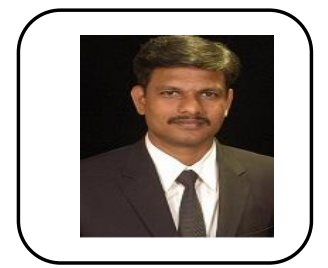

Ramesh Babu Chokkalingam completed his $\mathrm{Ph}$.D. from IIT Chennai. He has more than ten years of experience in teaching and research. His areas of research includes pervious concrete, geopolymer concrete, and high volume flyash concrete. 